\title{
Do I Speak Anxiously? A Correlation of Self-Efficacy, Foreign Language Learning Anxiety and Speaking Performance
}

\author{
Istanti Hermagustiana ${ }^{1}$, Anjar Dwi Astuti ${ }^{2}$, Didik Sucahyo \\ Universitas Mulawarman, Indonesia \\ Email Correspondence: istantihermagustiana@ @ fip.unmul.ac.id
}

\section{Background:}

Abstract

Self-efficacy and anxiety associated with foreign language learning are now recognized as two critical affective factors in foreign language learning. However, little is known about the relationships between these two affective variables and learners' performance while speaking. As a result, the current research aims to determine: EFL learners' self-efficacy, foreign language learning anxiety (FLLA), speaking performance, and the relationship between speaking performance and self-efficacy, speaking performance and FLLA, and selfefficacy and FLLA.

\section{Methodology:}

This research enlisted the participation of seventy sixth-semester students. Three testing instruments were used: a self-efficacy questionnaire, an FLLA questionnaire, and one speech test to assess students' speaking abilities.

Findings:

Based on these findings, the null hypothesis (Ho) was rejected while accepting the alternative hypothesis (Ha). As a result, there was a substantial positive association between speaking success and self-efficacy, as well as a negative correlation between speaking performance and FLLA and self-efficacy and FLLA. It means that students with high-level speaking performance will have high-level of self-efficacy. Then, the higher students' speaking performance is, the lower their FLLA becomes. It is in line with the correlation between students' selfefficacy and FLLA, that students with high-level of self-efficacy would have low FLLA.

\section{Conclusion:}

According to the findings of this study, self-efficacy and FLLA were both positively and negatively related to speaking performance. When the two affective variables were correlated to see whether they had a meaningful relationship, it was discovered that the relationship was both negative and important.

Keywords: EFL learners; foreign language learning anxiety (FLLA); self-efficacy; speaking performance

DOI $\quad:$ http//dx.doi.org/10.24903/sj.v6i1.696

\begin{tabular}{|l|l|l|}
\hline Received & $:$ & February 2021 \\
\hline Accepted & $:$ & March 2021 \\
\hline Published & $:$ & April 2021 \\
\hline
\end{tabular}

Authors retain copyright and grant the journal right of first publication with the work simultaneously licensed under a Creative Commons Attribution 4.0 International License that allows others to share the work with an acknowledgement of

Copyright Notice : the work's authorship and initial publication in this journal. 


\section{INTRODUCTION}

In language learning, Learners are able to communicate verbally and in writing, as well as share emotions, ideas, and experiences in a variety of contexts. Therefore, English as Foreign Language (EFL) learners uses the language that they have learned to communicate on which is also related to their emotional dimensions. Self-efficacy and anxiety are factors that oftentimes influence successful language learning. Furthermore, when faced with a stressful situation, specifically for foreign language learning, the individual's belief in their ability will affect the way the individual reacts to the situation. Schunk (2012) defined selfefficacy refers to perceptions of one's capabilities to produce actions; outcome expectations involve beliefs about the anticipated outcomes of those actions. Thus, students who perform well believe that they have competence and confidence with their effort.

Studies show the importance of self-efficacy in students' learning process. Research by Feyzioğlu (2019), Moreno \& Kilpatrick (2018), Sahin-Taskin (2018) examined that practice affects students' sense of self-efficacy in the foreign language classroom. Alsuhaibani (2019), Genç et al., (2016) show that students' beliefs on language learning are affected by their English self-efficacy. EFL students have medium scores in their English self-efficacy and held the strong belief that motivation factors have a great role in their learning process.

Additionally, anxiety becomes another factor which involves in language learning. It prevents them from developing their skills and harms their performance. Anxiety in the second language is defined as the sensation of stress and apprehension associated with second language contexts such as speaking, listening, and writing (Peter D MacIntyre \& Gardner, 1991). Nitko (1996) contends that teachers should be mindful of the language learning distress causes that can adversely affect students' success in order to promote higher levels of performance. Research by Liu (2012) examines EFL learners' anxiety in English classrooms and one of the results shows that anxiety primarily hampered students' performance and most of them were vulnerable to use English in their English class. 
English learners use four skills to learn English: listening, speaking, reading, and writing. In order to achieve the aim of learning English, speaking ability is the most important in communicating and provides several problems (El Shazly, 2021; Le \& Nguyen, 2021; Tridinanti, 2018). They are nervous when they are learning to talk. They will be unable to use the target language for fear of making an error. According to the English First English Proficiency Index (EF EPI), Indonesia ranked 39th out of 80 countries in 2017 with a ranking of 52.15. (Renandya et al., 2018). Thus, Indonesia remains at a poor degree of English proficiency and has not been able to discuss, mediate, petition, or compete with other countries in learning English (Tridinanti, 2018).

Studies have indicated the correlation between self-efficacy, anxiety and students' achievement. Shih (2019) investigates the process of goal setting, the L2 anxiety, the effort the learners put into, self-efficacy together with self-regulatory strategy as factors that contribute to learning achievement. The findings show that self-efficacy, L2 anxiety, and goal-setting process are prerequisites for applying an effective self-regulatory strategy. Furthermore, it is significant in influencing learners' intended efforts and their achievement. A study by Tridinanti (2018) examines the correlation between students' speaking anxiety, self-confidence, and speaking achievement. The result shows that speaking anxiety has no significant correlation with speaking achievement and self-confidence has a significant correlation with speaking achievement. Students may feel uneasy speaking English because they are not used to using the means of communication that they are used to (Aichhorn \& Puck, 2017; Nascente, 2001).

Based on the abovementioned explanation, the relationship between self-efficacy, foreign language learning anxiety and students' speaking performance in the context of higher education has rarely been examined. The sixth-semester students of the English Department, Mulawarman University are chosen to participate. They are believed to have more experience in foreign language classes and to be more knowledgeable in speaking classes compare to other students from the different semesters. By the result of the previous studies from Shih (2019) and Tridinanti (2018) the students are very likely to experience the influence of self-efficacy and anxiety on their achievement, specifically in speaking. Thus, this study aims at investigating self-efficacy, foreign language learning anxiety, speaking performance and the correlation between each of them in the sixth-semester students. 


\section{METHODOLOGY}

The research design in this study is a correlational design that aims to figure out the impact of self-efficacy and foreign language learning anxiety (FLLA) on the speaking performance of the sixth-semester students of the English Education Department, Mulawarman University. This study involved sixth-semester students from three separate classes. Therefore, seventy participants participated in this study.

This study utilized three research instruments comprising two questionnaires which demonstrated students' self-efficacy and FLLA, and one speaking test used to show students' speaking performance. The self-efficacy questionnaire consisting of 32 items was adapted from Wang et al., (2013) study. The validity and reliability of the questionnaire appeared to be highly reliable with a person reliability of 0,99 and item reliability of 0,98 . It means the questionnaire has a very high correlation and reliability. The questionnaire uses a Likert-scale question type in which five indicators are used: Strongly agree -5 ; Agree -4 ; Not sure -3 ; Disagree -2 ; and Strongly disagree -1 .

A FLLA questionnaire is the second questionnaire used in this study. Horwitz et al., (1986), Quinto \& MacAyan, (2020)Horwitz, developed it and it consists of 33 items. The validity and reliability of the anxiety questionnaire were 0,83 . It means the questionnaire has a very high correlation and reliability. Similar to the self-efficacy questionnaire, the FLLA questionnaire uses a 5 Likert-scale question type: Strongly agree - 5; Agree - 4; Not sure -3 ; Disagree -2 ; and Strongly disagree -1 .

The last instrument used is a speaking evaluation. There was a speaking test given to the students to measure their speaking performance. The test was recorded to make sure that the scorers fairly assessed the individual performance. Inter-rater reliability was applied in which three scorers were scoring the students' speaking performance to avoid test subjectivity. The scorers assessed the students' performance based on a speaking rubric which consists of a number of indicators, such as fluency, comprehensibility, vocabulary, and accuracy.

To collect data, the researchers carried out several procedures as follows: first, the first questionnaire of self-efficacy was distributed. After that, the questionnaire of foreign language learning anxiety was distributed to the participant a day after. Once the two questionnaires had been administered, students speaking performance was then assessed through a test and by three raters to minimize the subjectivity of the scores. The last stage of 
the data collection was correlating the score of the self-efficacy questionnaire and foreign language learning anxiety questionnaire to students' speaking scores by using Pearson correlation of SPSS.21 windows program. All the tests of the hypotheses refer to the 0.05 level of significance.

In order to reveal the correlation between self-efficacy and foreign language learning anxiety on speaking performance, the collected data will be quantitatively analyzed by using the Pearson correlation of the SPSS.21 windows program. The scores of each instrument were calculated using descriptive statistics which focused on finding the mean score and percentages. A short discussion of the provisions made (if any) for controlling bias or unintended causes of uncertainty, as well as the dataset limitations, should be included in the procedures.

\section{FINDINGS}

The data from this present study were all analyzed using SPSS.21 windows program. To analyze the data Pearson correlation coefficient, an independent group t-test was used. All the tests of the hypotheses refer to the 0.05 level of significance. Table 1 presents the frequency of self-efficacy, foreign language learning anxiety (FLLA) and speaking performance of the 70 students. In order to analyze EFL learners' self-efficacy, foreign language learning anxiety (FLLA) and speaking performance with their sub-dimensions, the results of 70 participants were grouped as high, moderate and low.

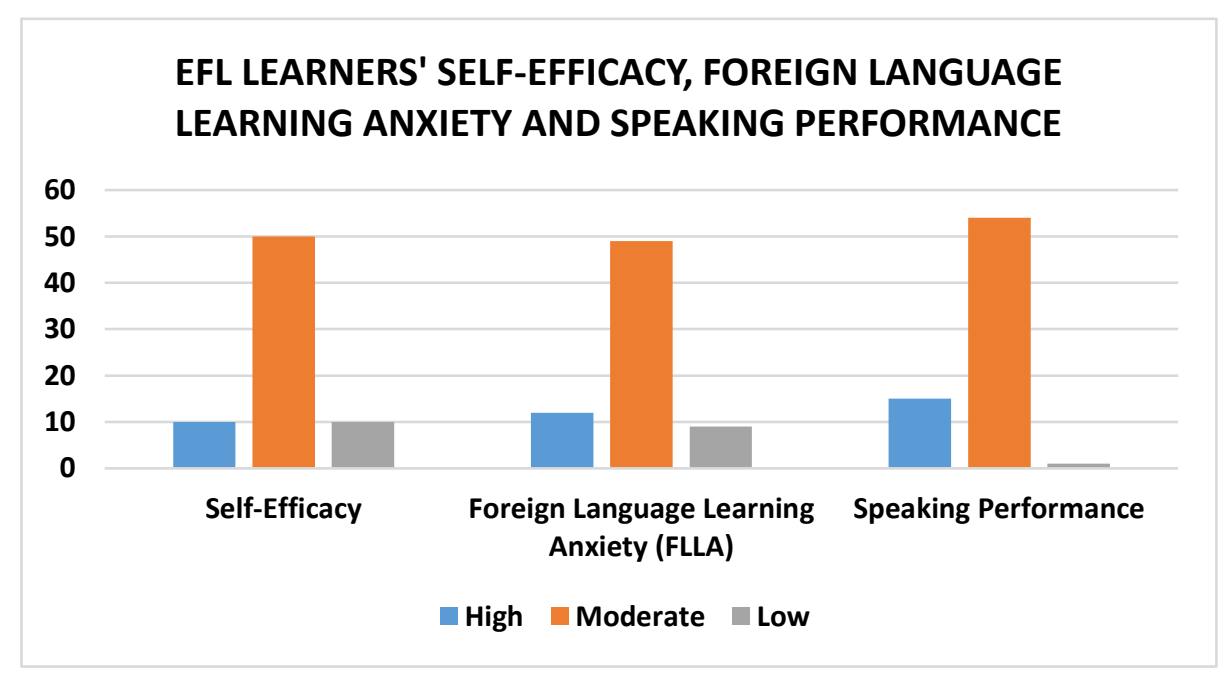

Figure 1. Frequency about self-efficacy, foreign language learning anxiety (FLLA) and speaking performance

The table shows that the participants mostly have a moderate level of self-efficacy $(\geq 50)$, FLLA $(<50)$ and speaking performance $(>50)$, and some of them were in a high $(\leq 15)$ and low level $(<10)$. The more detail of the descriptive statistics about those three aspects are presented in table 1: 
Table 1: Descriptive statistics about self-efficacy, foreign language learning anxiety (FLLA), and speaking performance.

Std.

\begin{tabular}{lccccc} 
& $\mathrm{N}$ & Minimum & Maximum & Mean & Deviation \\
\hline TSelf.Efficacy & 70 & 23.71 & 81.05 & 50.0000 & 10.00000 \\
\hline TAnxiety & 70 & 29.94 & 79.37 & 50.0000 & 10.00000 \\
\hline $\begin{array}{l}\text { Speaking } \\
\text { Performance }\end{array}$ & 70 & 20.00 & 82.00 & 73.5571 & 7.78262 \\
\hline
\end{tabular}

Valid N

(listwise) 70

The lowest minimum score belongs to EFL learners' speaking performance with 20.00 . It was followed by the self-efficacy score which was 23.71 and the FLLA score of 29.94 became the highest. Whereas for maximum score, the EFL learners' speaking performance was the highest with 82.00 and only 0.95 points lower was students' self-efficacy score and the FLLA score was the lowest with 79.37. Next, the mean score of the EFL learners' attitudes for self-efficacy and FLLA were 50.00000 and for the speaking performance was 73.5571. The last was the standard deviation scores that were 10.00000 for self-efficacy and FLLA and 7.78262 for the speaking performance.

Table 2 represents the relationship between students' speaking performance and their self-efficacy. A significant $(\mathrm{p}<0.05)$ positive correlation $(\mathrm{r}=.605)$ was detected between EFL learners' speaking performance and self-efficacy, which means the level of students' speaking performance went up along with the level of self-efficacy.

Table 2. Correlation between EFL learners' speaking performance and self-efficacy.

\begin{tabular}{llrr}
\hline & & Speaking_Performance & TSelf.Efficacy \\
\hline Speaking_Performance & $\begin{array}{l}\text { Pearson } \\
\text { Correlation }\end{array}$ & 1 & $.605^{* *}$ \\
\hline & $\begin{array}{l}\text { Sig. (2- } \\
\text { tailed) }\end{array}$ & 70 & .001 \\
\cline { 2 - 4 } & $\mathrm{N}$ & $.605^{* *}$ & 70 \\
\hline TSelf.Efficacy & $\begin{array}{l}\text { Pearson } \\
\text { Correlation }\end{array}$ & .001 & 1 \\
\cline { 2 - 4 } & $\begin{array}{l}\text { Sig. (2- } \\
\text { tailed) }\end{array}$ & 70 & 70 \\
\cline { 2 - 4 } & $\mathrm{N}$ & 70 & \\
\hline
\end{tabular}

The correlation between EFL learners' speaking performance and foreign language learner anxiety (FLLA) is shown in table 3. The $\mathrm{r}=-.466$ is indicating negative correlation, which means the higher the level of students' speaking performance is, the lower their FLLA becomes. 
Table 3. Correlation between EFL learners' speaking performance and self-efficacy.

\begin{tabular}{llrr}
\hline & & Speaking_Performance & TAnxiety \\
\hline Speaking_Performance & $\begin{array}{l}\text { Pearson } \\
\text { Correlation }\end{array}$ & 1 & $-.466^{* *}$ \\
\cline { 2 - 4 } & $\begin{array}{l}\text { Sig. (2- } \\
\text { tailed) }\end{array}$ & 70 & .001 \\
\cline { 2 - 4 } $\mathrm{N}$ & $\begin{array}{l}\text { Pearson } \\
\text { Correlation }\end{array}$ & $-.466^{* *}$ & 70 \\
\hline $\begin{array}{l}\text { Sig. (2- } \\
\text { tailed) }\end{array}$ & .001 & 1 \\
\cline { 2 - 4 } $\mathrm{N}$ & 70 & 70 \\
\hline
\end{tabular}

The last correlation is between students' self-efficacy and FLLA depicted in Table 4. The result clarifies that there is a negative correlation $(r=-.518)$ between students' selfefficacy and their FLLA. As self-efficacy decreases, FLLA increases.

Table 4. Correlation between EFL learners' self-efficacy and foreign language learner anxiety (FLLA)

\begin{tabular}{llll}
\hline \multirow{2}{*}{ TSelf.Efficacy } & \multicolumn{1}{c}{ TSelf.Efficacy } & TAnxiety \\
& $\begin{array}{l}\text { Pearson } \\
\text { Correlation }\end{array}$ & 1 & $-.518^{* *}$ \\
\cline { 2 - 4 } & Sig. (2-tailed) & 0.001 \\
\cline { 2 - 4 } & $\mathrm{N}$ & 70 & 70 \\
\hline TAnxiety & Pearson & $-.518^{* *}$ & 1 \\
& Correlation & & \\
\cline { 2 - 4 } & Sig. (2-tailed) & 0.001 & 70 \\
\cline { 2 - 4 } & $\mathrm{N}$ & 70 & \\
\hline
\end{tabular}

\section{DISCUSSION}

The current study was investigating the relationship between two affective variables in learning a foreign language, namely self-efficacy and foreign language learning anxiety toward students' speaking performance. Both negative and positive correlations were revealed.

\subsection{Self-efficacy and speaking performance}

This study examines two affective factors of learning a language: self-efficacy and foreign language learning anxiety, and English learners' speaking performance. For the first correlation, it was revealed that self-efficacy showed a strongly positive correlation to learners' speaking performance. This finding echoed a number of previous studies (Anyadubalu, 2010; El Shazly, 2021; Erkan \& Saban, 2011; Li \& Wang, 2010; Quinto \& MacAyan, 2020; Sabti et al., 2019; Tridinanti, 2018). This implies that it is inevitable that self-efficacy be cultivated to increase learners' English performance, particularly speaking. 
Pertaining to this, Bandura (1993) discovered that an individual's self-efficacy influences how they handle goals, activities, and obstacles. In other words, self-efficacy clearly predicts goal-setting and academic success in learners. It implicitly affects learners' academic success through the mediator of goal-setting. As a result, the study concludes that the higher a language learner's self-efficacy, the more likely the goal-setting process would be effective. Furthermore, the higher one's self-efficacy, the lower one's academic success.

\subsection{FLLA and speaking performance}

The finding affirmed that foreign language learning anxiety and speaking performance exhibited a negative relationship. Theoretically, a high degree of learning anxiety often leads to a poor outcome, while learners with a low level are expected to do well (Erkan \& Saban, 2011; Genç et al., 2016; Pajares, 2003). In other words, learners with a high anxiety level attempt to avoid speaking tasks since they find it a threat rather than a challenge. It means that lack exposure of English language leads to learners' low speaking performance. This finding is consistent with previous research, which has shown that as students gain proficiency in the target language, their anxiety level declines (Brown, 2001; P. D. MacIntyre \& Gardner, 1989). There is a tendency that the participants feel discouraged to improve their speaking performance caused by learning anxiety known as one of the problems in the speaking class. Suwanarak (2012) states that being fearless and confident when studying or using a language can encourage achievement and successful results. However, the finding of this study was slightly different from that theoretical perspective. It was revealed that the learning anxiety level of the participants was moderate, whereas it was discovered that there was only one participant out of 70 EFL learners obtained a low score. This indicates that the low result the participant received might not result from the learning anxiety. In this case, there may be some other influencing factors causing the bad speaking performance.

\subsection{Self-efficacy and FLLA}

The third correlation investigated was that of self-efficacy and learning anxiety. The study result confirmed that self-efficacy and learning anxiety was negatively correlated. This suggests that those two affective factors of learning a language have diverse impacts on learners. It implies that the higher self-efficacy learners possess, the lower anxiety they have, or vice versa. This is in line with Ringeisen et al., (2019) \& Soysa \& Wilcomb (2015) reporting that when people experience high fears, anxiety, or high levels of stress, they usually have low self-efficacy. On the other hand, those who have high self-efficacy feel 
capable of being successful in overcoming obstacles and perceiving threats as a challenge that should not be avoided.

Prior studies have uncovered a negative correlation between learners' anxiety and selfefficacy in first and second language (Enisa \& Karairmak, 2017; Piniel \& Csizér, 2013; Singh \& Rajalingam, 2012; Tahmassian \& Moghadam, 2011). For example, Tahmassian \& Moghadam (2011) found out a significant and negative correlation between self-efficacy and foreign language learning anxiety. Despite a report that found the anxiety and self-efficacy levels to be extremely uncorrelated (Cubukcu, 2008; Feyzioğlu, 2019), the repetition of this mild negative association in several studies is firm evidence of the reverse impact of selfefficacy on learning anxiety. As a result, language teachers must consider all learners' expectations of their competence and their success. According to Alsuhaibani (2019) \& Bandura (2010), self-efficacy is a good indicator of learners' competence and success.

To summarize, self-efficacy has an important role in improving students' speaking performance. This could be achieved when FLLA is reduced. This study's results show that both high self-efficacy and low FLLA affect students' speaking performance. According to Piechurska-Kuciel (2013) self-efficacy refers to an individual's beliefs about his or her ability, and it influences the attempts he or she makes to attain desirable results, besides that selfefficacy is useful for exercising control of anxiety outbreaks. However, there are some drawbacks to the present research that must be considered. Since this is a preliminary analysis, more research is needed to find out qualitative evidence on the two affective variables, such as how participants can improve their self-efficacy and reduce their anxiety when learning a foreign language. Furthermore, the participants were restricted to undergraduate students from a single department. More participants from different departments in other faculties relevant to English are available for outcome generalization. In summary, both self-efficacy and foreign language acquisition fear must be researched thoroughly in order to make a significant contribution to the success of students at all levels.

\section{CONCLUSION}

This research discovered that self-efficacy and FLLA were both positively and negatively linked to speaking performance. When those two affective factors were correlated to find out whether they both had a significant relationship, it was found out that the relationship was negative and significant. Self-efficacy and foreign language learning anxiety were negatively correlated since the higher self-efficacy the participants had, the lower FLLA 
they possessed. It means that self-efficacy is an important aspect that needs to be developed by the language learners in order that they can achieve a low FLLA level which leads to the success of learning a foreign language. Moreover, the participants' speaking performance was both positively and negatively correlated with self-efficacy and FLLA based on the present empirical study. In other words, successful speaking performance could be achieved when the language learners have got high self-efficacy but low FLLA levels.

The study's latest findings have a host of consequences for teacher preparation systems. To continue, university teacher educators should be given theoretical information on foreign language speaking anxiety and invited to provide solutions on how this specific issue can be reduced in undergraduate programs. Furthermore, teacher educators should include university students in small dialogue groups so that they can exchange thoughts in a supportive learning setting. This will assist students in increasing their self-efficacy and decreasing learning anxiety, allowing them to produce successful speaking results. Finally, lecturers and students should collaborate to identify the major causes that should be included in undergraduate programs to ensure non-threatening speech environments.

\section{REFERENCES}

Aichhorn, N., \& Puck, J. (2017). “I just don't feel comfortable speaking English”: Foreign language anxiety as a catalyst for spoken-language barriers in MNCs. International Business Review, 26(4), 749-763.

Alsuhaibani, Z. (2019). The relationship between female EFL students' use of reading strategies and their reading self-efficacy. International Journal of Arabic-English Studies, 19(2), 373-394. https://doi.org/10.33806/ijaes2000.19.2.8

Anyadubalu, C. C. (2010). Self-efficacy, anxiety, and performance in the English language among middle-school students in English language program in Satri Si Suriyothai School, Bangkok. International Journal of Human and Social Sciences, 5(3), 193-198. https://citeseerx.ist.psu.edu/viewdoc/download?doi=10.1.1.309.5940\&rep=rep1\&type=p df

Bandura, A. (1993). Perceived Self-Efficacy in Cognitive Development and Functioning. Educational Psychologist, 28(2), 117-148. https://doi.org/10.1207/s15326985ep2802_3

Bandura, A. (2010). Self-efficacy. The Corsini Encyclopedia of Psychology, 1-3.

Brown, H. D. (2001). Teaching by Principles as Interactive Approach to Language Pedagogy (2nd ed.). Pearson Education.

Cubukcu, F. (2008). A Study on the Correlation between Self Efficacy and Foreign Language Learning Anxiety. Online Submission, 4(1), 148-158.

El Shazly, R. (2021). Effects of artificial intelligence on English speaking anxiety and speaking performance: A case study. Expert Systems, 38(3).

https://doi.org/10.1111/exsy.12667 
Enisa, M., \& Karairmak, Ö. (2017). The predictor roles of speaking anxiety and english self efficacy on foreign language speaking anxiety. Journal of Teacher Education and Educators, 6(1), 117-131. https://dergipark.org.tr/en/pub/jtee/issue/43270/525680

Erkan, D. Y., \& Saban, A. İ. (2011). Writing performance relative to writing apprehension, self-efficacy in writing, and attitudes towards writing: A correlational study in Turkish tertiary-level EFL. The Asian EFL Journal Quarterly March 2011 Volume 13, Issue, 13(1), 164-192. https://www.scopus.com/record/display.uri?eid=2-s2.0$84856185303 \&$ origin $=$ resultslist $\&$ sort $=$ plf$\mathrm{f} \& \mathrm{src}=\mathrm{s} \& \mathrm{sid}=4124832922326414 \mathrm{cbf5364e} 8362 \mathrm{ff} 6 \mathrm{e} \& \mathrm{sot}=\mathrm{b} \& \mathrm{sdt}=\mathrm{b} \& \mathrm{sl}=93 \& \mathrm{~s}=$ TITLEABS-KEY\%2528Writing+performance+relative+to+writing+apprehension\%252C+selfefficacy+in+writing $\% 25$

Feyzioğlu, B. (2019). The role of inquiry-based self-efficacy, achievement goal orientation, and learning strategies on secondary-school students' inquiry skills. Research in Science and Technological Education, 37(3), 366-392. https://doi.org/10.1080/02635143.2019.1579187

Genç, G., Kuluşakli, E., \& Aydin, S. (2016). Exploring prospective EFL teachers' perceived self-efficacy and beliefs on english language learning. Australian Journal of Teacher Education, 41(2), 53-68. https://doi.org/10.14221/ajte.2016v41n2.4

Horwitz, E. K., Horwitz, M. B., \& Cope, J. (1986). Foreign Language Classroom Anxiety. The Modern Language Journal, 70(2), 125-132. https://doi.org/https://doi.org/10.2307/327317

Le, V. H. H., \& Nguyen, H. N. (2021). Mobile phones' video recording tool: A solution to freshmen's english-speaking anxiety. International Journal of Computer-Assisted Language Learning and Teaching, 11(2), 16-32. https://doi.org/10.4018/IJCALLT.2021040102

Li, Y., \& Wang, C. (2010). An empirical study of reading self-efficacy and the use of reading strategies in the Chinese EFL context. Asian EFL Journal, 12(2), 144-162.

Liu, M. (2012). Language Anxiety in Chinese university EFL learners in varying learning contexts. Indonesian JELT: Indonesian Journal of English Language Teaching, 8(1), 121. https://doi.org/https://doi.org/10.25170/ijelt.v8i1.1528

MacIntyre, P. D., \& Gardner, R. C. (1989). Anxiety and Second-Language Learning: Toward a Theoretical Clarification*. Language Learning, 39(2), 251-275. https://doi.org/10.1111/j.1467-1770.1989.tb00423.x

MacIntyre, Peter D, \& Gardner, R. C. (1991). Investigating language class anxiety using the focused essay technique. The Modern Language Journal, 75(3), 296-304. https://doi.org/https://doi.org/10.2307/328723

Moreno, R., \& Kilpatrick, J. (2018). Student perceptions of self-efficacy in the foreign language classroom: A design-based research study. EDeR. Educational Design Research, 2(1). https://doi.org/https://doi.org/10.15460/eder.2.1.1214

Nascente, R. (2001). Ways to deal with anxiety. English Teaching Professional, 19, 18-20.

Nitko, A. J. (1996). Educational assessment of students. ERIC.

Pajares, F. (2003). SELF-EFFICACY BELIEFS, MOTIVATION, AND ACHIEVEMENT 
IN WRITING: A REVIEW OF THE LITERATURE. Reading \& Writing Quarterly, 19(2), 139-158. https://doi.org/10.1080/10573560308222

Piechurska-Kuciel, E. (2013). Self-efficacy in L2: A research proposal. Second Language Learning and Teaching, 18, 31-42. https://doi.org/10.1007/978-3-319-00161-6_3

Piniel, K., \& Csizér, K. (2013). L2 motivation, anxiety and self-efficacy: The interrelationship of individual variables in the secondary school context. Studies in Second Language Learning and Teaching, 3(4). https://www.ceeol.com/search/articledetail?id=104506

Quinto, E. J. M., \& MacAyan, J. V. (2020). Interactive influence of anxiety and goal orientation in predicting language task performance of filipino engineering students. Asian ESP Journal, 16(21), 335-359. https://www.scopus.com/inward/record.uri?eid=2s2.0-85087114756\&partnerID=40\&md5=87176c1561c436bed22beef3118f9ee2

Renandya, W. A., Hamied, F. A., \& Nurkamto, J. (2018). English language proficiency in Indonesia: Issues and Prospects. Journal of Asia TEFL, 15(3), 618.

Ringeisen, T., Lichtenfeld, S., Becker, S., \& Minkley, N. (2019). Stress experience and performance during an oral exam: the role of self-efficacy, threat appraisals, anxiety, and cortisol. Anxiety, Stress, \& Coping, 32(1), 50-66.

Sabti, A. A., Md Rashid, S., Nimehchisalem, V., \& Darmi, R. (2019). The Impact of writing anxiety, writing achievement motivation, and writing self-efficacy on writing performance: A correlational study of Iraqi tertiary EFL Learners. SAGE Open, 9(4), 2158244019894289. https://doi.org/https://doi.org/10.1177\%2F2158244019894289

Sahin-Taskin, C. (2018). Effects of active learning environments supported with self- and peer assessment on pre-service teachers' pedagogical and self-efficacy beliefs. AsiaPacific Journal of Teacher Education, 46(5), 421-440. https://doi.org/10.1080/1359866X.2017.1355049

Schunk, D. H. (2012). Learning theories an educational perspective sixth edition. Pearson. https://www.pearson.com/us/higher-education/product/Schunk-Learning-Theories-AnEducational-Perspective-6th-Edition/9780137071951.html

Shih, H.-J. (2019). L2 Anxiety, Self-Regulatory Strategies, Self-Efficacy, Intended Effort and Academic Achievement: A Structural Equation Modeling Approach. International Education Studies, 12(3), 24-35.

Singh, T. K. R., \& Rajalingam, S. K. (2012). The Relationship of Writing Apprehension Level and Self-Efficacy Beliefs on Writing Proficiency Level among Pre-University Students. English Language Teaching, 5(7), 42-52.

Soysa, C. K., \& Wilcomb, C. J. (2015). Mindfulness, self-compassion, self-efficacy, and gender as predictors of depression, anxiety, stress, and well-being. Mindfulness, 6(2), 217-226.

Suwanarak, K. (2012). English language learning beliefs, learning strategies and achievement of Masters students in Thailand. TESOL in Context S, 3, 1-15.

Tahmassian, K., \& Moghadam, N. J. (2011). Relationship between self-efficacy and symptoms of anxiety, depression, worry and social avoidance in a normal sample of students. Iranian Journal of Psychiatry and Behavioral Sciences, 5(2), 91. 
Tridinanti, G. (2018). The correlation between speaking anxiety, self-confidence, and speaking achievement of Undergraduate EFL students of private university in Palembang. International Journal of Education and Literacy Studies, 6(4), 35-39. https://doi.org/http://dx.doi.org/10.7575/aiac.ijels.v.6n.4p.35

Wang, C., Kim, D.-H., Bong, M., \& Ahn, H. (2013). Examining measurement properties of an English Self-Efficacy scale for English language learners in Korea. International Journal of Educational Research, 59, 24-34. https://doi.org/10.1016/j.ijer.2013.02.004 